\title{
ERRATUM
}

\section{A meta-analysis and transmission disequilibrium study of association between the dopamine D3 receptor gene and schizophrenia}

J Williams, G Spurlock, P Holmans, R Mant, K Murphy, L Jones, A Cardno, P Asherson, D Blackwood, W Muir, K Meszaros, H Aschauer, J Mallet, C Laurent, P Pekkarinen, J Seppala, CN Stefanis, GN Papadimitriou, F Macciardi, M Verga, C Pato, H Azevedo, M-A Crocq, H Gurling, G Kalsi, P McGuffin, MJ Owen. Mol Psychiatry 1998; 3: 141-149.

D Curtis should not have been listed as an author in this article. 